\title{
Technology Policy Implementation Road: Exploring Firms’ Technology Readiness in a Mandatory Vertical Diffusion Environment
}

\author{
Victoria E. Erosa \\ International Graduate Center (IGC), University of Applied Sciences (Hochshule), Bremen, Germany. \\ Email: erosav@usa.net
}

Received October $2^{\text {nd }}, 2013$; revised November $6^{\text {th }}, 2013$; accepted November $28^{\text {th }}, 2013$

Copyright (C) 2013 Victoria E. Erosa. This is an open access article distributed under the Creative Commons Attribution License, which permits unrestricted use, distribution, and reproduction in any medium, provided the original work is properly cited. In accordance of the Creative Commons Attribution License all Copyrights (C) 2013 are reserved for SCIRP and the owner of the intellectual property Victoria E. Erosa. All Copyright (C) 2013 are guarded by law and by SCIRP as a guardian.

\begin{abstract}
Technology Transfer and Technology Diffusion body of knowledge emerge from the research interest to explore the demand side of technology transfer by identifying the firm's technology readiness to operate a new technology-product and process - in the context of the transfer of technology from a single source to multiple receivers/users - termed vertical diffusion-, where the adoption is by mandate. Demarcating the e-Invoice document as technology transfer object, this paper presents results of quantitative study performed with data collected from a 137 small retail firms, oriented to identify their technology readiness in terms of technology infrastructure and skills to operate under the electronic invoice legal procedure, as well as their perceived barriers for the diffusion. Results of factor analysis reveal insufficient information among all the participant firms, reflecting poor communication from the technology source, low awareness for the software solution available and of the competences/skills required to operate it as well as a passive attitude from the adopter who leans in a third party option to face the mandate.
\end{abstract}

Keywords: Technology Transfer; Vertical Diffusion; Technology Readiness; e-Invoice; Business Practices

\section{Introduction}

Two key Management of Technology (MOT) concepts to take a technological innovation to its end user had been largely studied: Technology Transfer and Technology Diffusion. Defined as the transfer of systematic knowledge for the manufacture of a product or provision of a service [1], as the movement of science and technology from one group to another [2], and as the movement of know-how, technical knowledge, or technology from one organizational setting to another [3], Technology Transfer addresses the assessment, adoption and implementation of technology. There is more than a two decades tradition of research on Technology Transfer topic as evidenced by works of Zhao and Reisman [4] (1992) and Bozeman [5] who claim to have found 579 works from period 1975-1999 in the Georgia Tech card catalog as well as 1032 online published articles during 1990-1999 period. This body of work related to international technology transfer and/or transfer in the private sector from one company or institution to other receives little attention here, being the focus and research interest in the context of the transfer of technology from a single source to multiple receivers/users [6,7].

Technology Diffusion relates to the process by which an innovation is communicated through certain channels over time among the members of a social system ([8], being referred as vertical dissemination when referring to diffusion from a technical source to receiver [9]. Issues on the matter had been reviewed thoroughly in the context of Information Technology (IT) diffusion [10], mainly under the assumption of adopters making voluntary decisions to accept or reject the technology use according to the expected benefits to generate. From the supply side or technology source view, IT diffusion moves in the range of (1) adoption by management encouragement [11], to (2) adoption by mandate [12].

This body of knowledge emerge from the interest to explore the Technology Transfer perspective related to 
implementation of public technology policies affecting the whole span of business environment at national level-adoption by mandate-, being the Government the source of technology transfer (one point source) and the universe of taxpayers of a country the receivers (multiple points/massive users), in diffusion literature is known as vertical diffusion [9]. Application of the referred term by mandate to a specific context in a massive environment is not yet found in MOT literature. Upon this view, moving such concepts as Technology Transfer and Technology Diffusion from theoretical to the application arena reveals to be a much complex task to manage, mainly when introducing facts such as the user's technology readiness to engage in mandatory use of technology based business process. The complexity of such a research context is shown in Diagram 1, where is clear that either at national or corporate level, it all starts in the Technology Policy dimension.

Moving to electronic processes implementation to gain efficiencies and enhance competitiveness, is made by business and government agencies as well. Due to its operational nature, IT is subject to be adopted by gov- ernment agencies to support service and operational processes (e-Government), being at the same time subject to public technology policies definition oriented to define technology infrastructure support, public investments, operational guidelines and rules, and other topics such as tax benefits to obtain by technology use introduction and/ or innovation activities. Under this circumstances, government is identified as the technology source or technology supply side for provision of a service to the country's population. Considering that Technology Transfer addresses the assessment, adoption and implementation of technology [1], the notion of technology user or technology receiver should be taken into account. In MOT arena, this practice in which the technology supply side seeks for a matching technology demand is identified as the technology push perspective of the technology transfer stage of the innovation life cycle [13-15].

As concepts move to operational field questions arousesuch as whom the user might be? Are they ready to use the technology to be implemented? - concepts of other disciplines such as supply and demand are introduced from Economic Theory as well as customer profile and

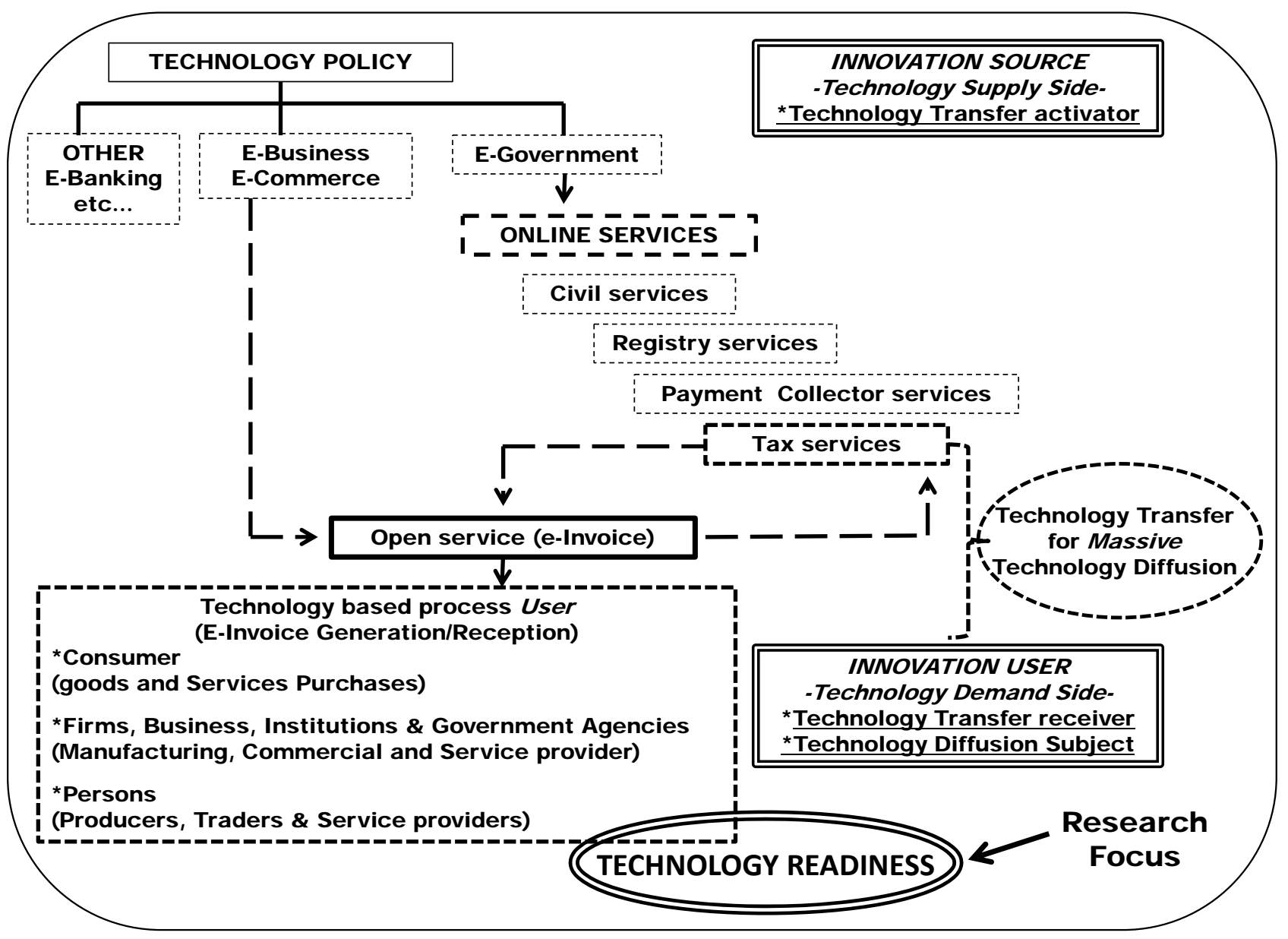

Diagram 1. Research focus context. 
market segments from Market Theory. Among these concepts is the one correspondent to Customer Profile which is translated into MOT language as the user or innovation receiver to be. In the realm of technology user analysis emerge the interest of Technology Readiness to receive and use the new technology. Technology Transfer research points that Technology Transfer is difficult both to research and to manage in part because the circumstances surrounding the interaction between technology development sources and technology receivers differ from transfer to transfer, even within the boundaries of a single organization [16].

Upon this premises, efficient transfer from the innovation and/or technology development (I/TD) sources to receivers requires information input regarding the receiver/user/customer's profile, to gain deep understanding of the context of technology application and about the capabilities for the technology based process operation. Putting the pieces together the research interest is to explore the demand side of technology transfer by identifying the firm's technology readiness to operate a new technology - product and process - in the context of the transfer of technology from a vertical diffusion perspective, understood as a single source to multiple receivers/users, where the adoption is by mandate.

This complex context of interest is operationalized in a research purpose in which boundaries are set in the retail small size firms segment to engage in electronic processes in response to mandatory technology policies of a country, as a means to generate information useful for the technology implementation process. This paper addresses these concepts implementation issue, considering that the economic benefits of new technology depend on the embedding of technology in society, and in consistency with the research trend that states that Technology policy will have to swift the attention from the supply side - new technology - to the demand side: technology users and consumers [17]. Analysis in such a research context provides its unique characteristic to this paper supporting the originality of the study object.

\section{Theoretical References}

\subsection{Technology Transfer}

The view of Technology as the ensemble of theoretical and practical knowledge and skills used by firms to develop and produce goods and services [18], is consistent with the conceptual approach for Technology Transfer mentioned in the work regulation of the United Nations [1], where is viewed as the transfer of systematic knowledge for the manufacture of a product or provision of a service. Traditionally Technology transfer has was conceptualized as the transfer of hardware objects, but today also involves information [19]. This view is related to the movement of knowledge of products and services from one firm to another, as in the case of knowledge embodied in new physical products or disembodied in other forms of technical knowledge. Another approach to Technology Transfer is related to the transfer mode or method [20-22]. It is widely recognized that effective Technology Transfer requires careful handling of the tacit knowledge of its developers [23], as well as a deep understanding of the context of application [24]. From the process view, Technology Transfer relies on organizational and individuals capabilities as key success issues.

\subsection{Technology Diffusion}

Literature on the topic makes clear that diffusion can be contrasted with innovation which refers to knowledge, products, and processes development [25]. Due to the e-Invoice characteristics, firms and tax payers operating under the traditional paper environment perceive this electronic document and its operational process as an innovation. Following Rogers [18] concept, an innovation is an idea, practice or project that is perceived as new by an individual or other unit of adoption, while diffusion is the process by which an innovation is adopted by members of a certain community, being influenced by four factors: 1) the innovation itself; 2) the communication channels used to spread information about the innovation; 3) time and 4) as in Spinardi [23], the nature of the society to whom it is introduced [26]. This view also involves the dissemination of know-how and technical information, as well as further adoption by users. Regarding this topic, Leonard-Barton [27] pointed that usually the end user of the innovation is not the decision maker person. For e-Invoice transfer and diffusion this argument is settled by the unique characteristic of a perceived innovation resulted from a Macro Policy determination, specifically a Tax Policy, therefore the end user is subject to the four stages of a innovation decision making process: 1) knowledge derived from information; 2) persuasion/perceived usefulness of the technology; 3) decision for the technology use which leads to implementation and 4) evaluation/decision confirmation.

The implication of the difference between adopter and end user [27] for the diffusion of the e-Invoice is that firms are adopters and operative personnel are users of the technology, while customers are involved as recipeents of the legal document issued. In this research, being mandatory e-Invoice adoption decision making do not depends on the adopter firm, yet competence and skills development refers to individual users. As potential users face uncertainty and information costs regarding the process and the rules to work with the e-Invoice, as well a technology infrastructure shortage, failures could exist 
in the process of e-Invoice diffusion. Additionally learning costs, operational lack of expertise and/or ignorance regarding the impact of the document in the business practices are other structurally barriers against technology diffusion [28].

Some actions suggested by Shapira and Rosenfeld [25] to overcome this potential barriers are, a) for adopters: awareness-building and technology demonstration, which seek to make potential users more knowledgeable about available technologies, their possible applications, benefits and costs (see SAT webpage) and efforts that aim to reduce the information search costs associated with technology diffusion; b) for the users: technical assistance and consultancy, support experts to assess business problems, and assistance during implementation. Intensive training options to avoid subsequent inefficiencies of use are conducted in forms such as on-the job training, classroom training, on-line training (tutorials, demos, etc.) team-building workshops and other learning formats. Due to the pressure for adoption it is expected that during the implementation stage, the users will turn to peers or "someone like me" as a highly reliable source of information, perceiving that experienced users have more credibility than the official sources of information, as in the vertical diffusion concept discussed by Leonard-Barton and Rogers [9]. The Theoretical Framework used for the analysis is presented in Diagram 2.

\section{The Study}

\subsection{Demarcating the Transfer Object}

Recognized as a key challenge in technology transfer actions, the demarcation of the transfer object [5], is the starting point in this research oriented to identify the existing match between mandatory technology use-derived from technology policies-, and the technology readiness of the users to be. A unique opportunity to gain understanding on the demand side of a vertical diffusion technology transfer context is provided by a mandatory technology policy of a Latin American country in which the compulsory introduction at country level of a commercial document in electronic format-with the same value than

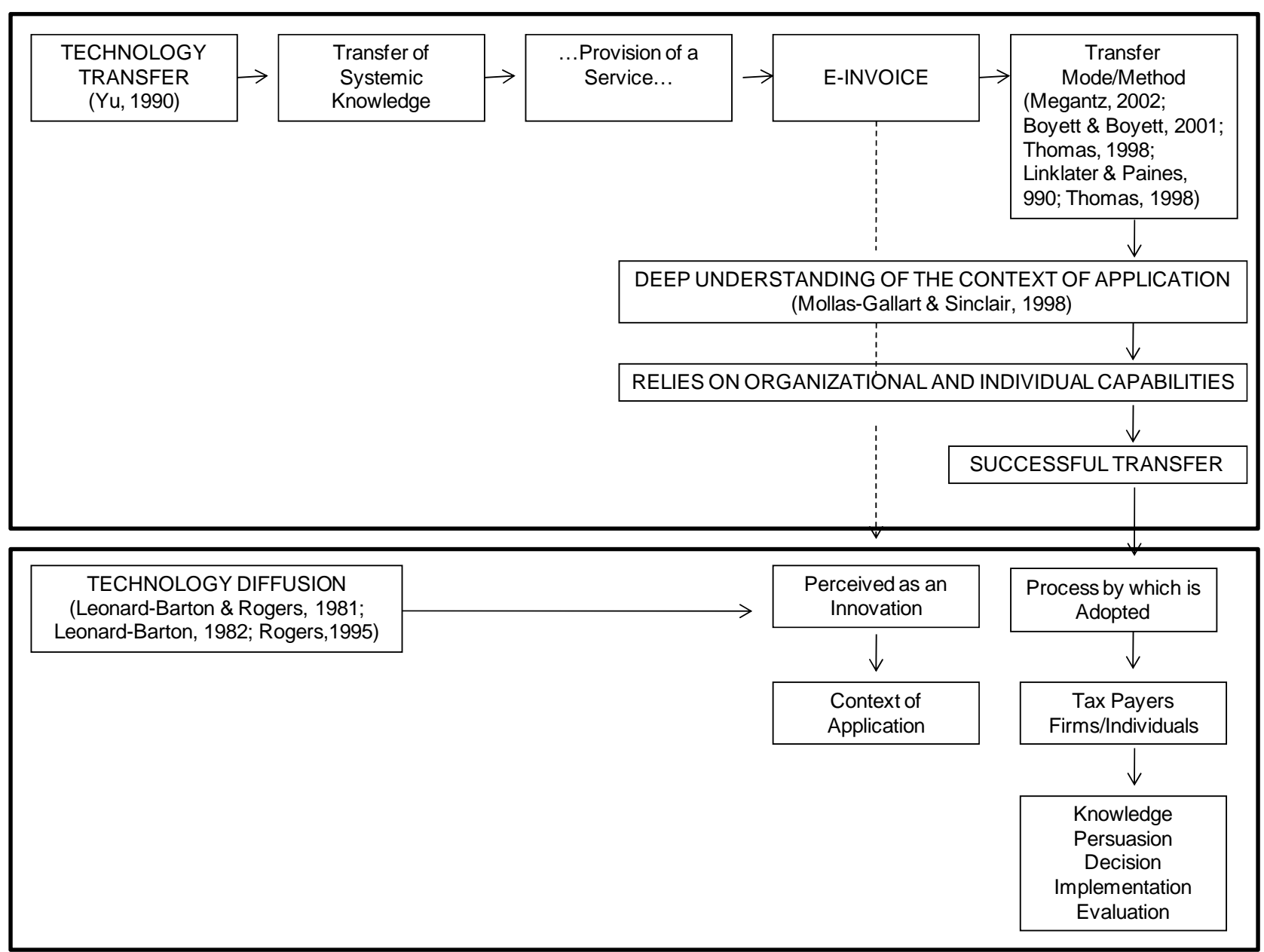

Diagram 2. Theoretical reference framework. 
its paper predecessor - raises various questions regarding the standardized technology readiness required among all users-to-be. The electronic document denominated eInvoice is demarcated as the object of technology transfer from the Government as technology source to the taxpayers as technology users. Consistent with $\mathrm{Yu}$ [1], e-invoice mandatory use represents the transfer of systematic knowledge for a service provision (tender an electronic document from the seller to the buyer), using a technology platform to operate a business operational procedure through electronic means. For this reason in this research it is not merely considered as the transfer of the software application but also knowledge and skills for its use and operation [29].

\subsection{Technology Description}

Electronic Document. An invoice is a document that verifies the closing of a commercial transaction between buyer and seller, when is prepared with electronic means is transformed into an electronic voucher or e-Invoice. In the country of the study setting (Mexico), e-Invoice follows the legal standards defined by the Budget Act (Miscelanea Fiscal) of the year 2004 in its Annex 20 [30], providing the legal validity for the generation, transmission and custody of the document by electronic means in XML format (open, flexible, portable, legible and accurate. As shown in a Digital Fiscal Certificate (e-Invoice) issued in September 2013 for a USD 18 laundry payment of Figure 1-received through the taxpayer e mail address - each issued e-Invoice comprises a digital stamp or electronic signature that corroborates the origin and provides validity to the Fiscal Agency (SAT, equivalent to the IRS) and a folio to identify the transaction number. Electronic signature operates as an invoice coded summary content.

E-Invoice components. The e-invoice components includes data of the firm/person that issues the invoice (1.1), receiver customer data (1.2), time and date of document generation (2.0), transaction concept (3.0), year and approval number (2.2), serial number (2.3), and folio approval number (2.1), (4.0) original electronic chain (public code cryptography using RSA Private Encrypt Algorithm and RSA Public Decript Algorithm, security $1.15 \times 10^{77}$ possible combinations), digital fiscal number or electronic signature/stamp (5.0). Data conservation is regulated by the Mexican Official Standard, NOM-151. To deal with such technical characteristics firms require technical infrastructure consisting in computers, wide band internet access, an e-invoice software to run Windows operative system $3 \times, \mathrm{XP}$ or larger, Web page, Pentium II Processor, printing peripherals and a registered electronic signature certificate.

Fixed and Variable components: Additional data relevant for the firm or business partners such as supplier code, purchase order number or product series, are integrated in a specific camp or format within the XML file of the e-Invoice termed "addenda". XML schema creates business communication between business data and process models. As the content of the addenda is not regulated by the SAT each firm is free to define the information and structure in a format consistent with the e-Invoice receptor requirements, usually contains data structured as an element, attribute, condition, data type and description. While the e-Invoice is a tax document, the addenda contains commercial information from the firms' client or business partners' interest, being many addenda as clients' requirements. This component adds a characteristic to the e-Invoice document: a fixed requirement for tax purpose and a variable component for business information identification that could be integrated or not.

Technology Availability. In November, 2010, were identified on the web 27 e-invoice software suppliers authorized by SAT to operate in the country, targeting SMEs and Large firms. Software suppliers are concentrated in the five major cities of the country, suggesting an uneven technology distribution and support. The number moved to more than 100 in July 2013, with a new diffusion option consisting in the emergency of former paper invoice

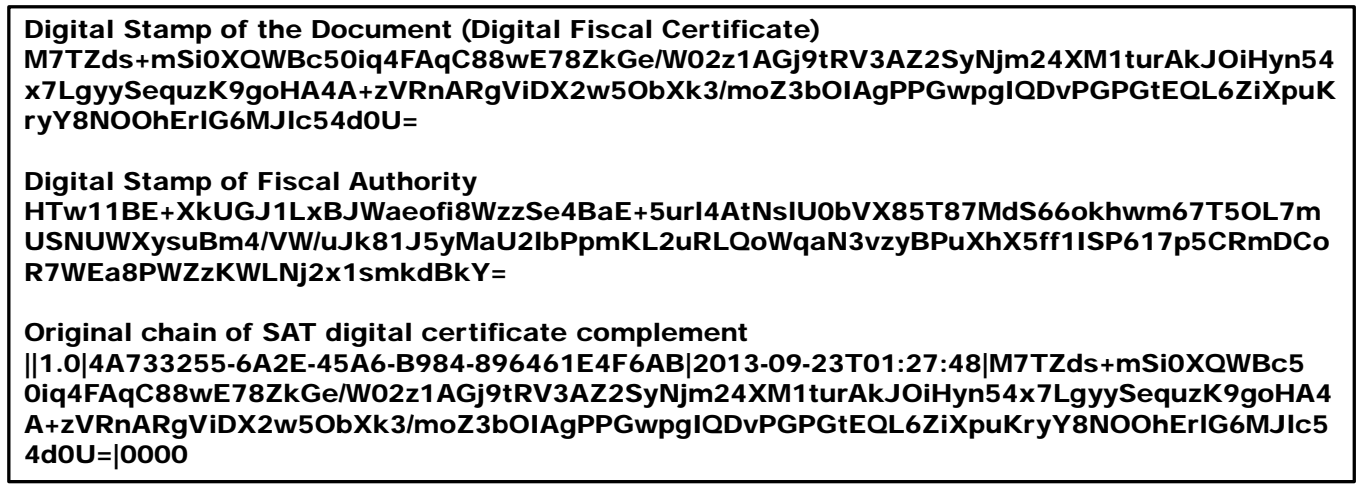

Figure 1. Digital stamps in e-invoice. 
printers and accountancy bureaus as e-Invoice folio suppliers from whom few unit series can be purchased by small users along the fiscal year to cover specific requirements.

\subsection{Business Processes Involved}

Electronic invoicing includes business processes, such as the followed by the seller to generate and register the invoice - with the regulatory requirements fulfilled — and the customer's payment mode, in the electronic mode this process includes the tax authority on-time operation register for both parties involved in the commercial transaction. Some of the reasons for changing this mandatory document to electronic means are the expected benefits such as cost reductions due to paperless printing, high volume speed emission, processing time reduction and archive custody security of the resulting transactions. In this new process several players are involved: from the supply side, the e-Invoice source of change is the Government Agency responsible of the tax payment management at national level (Tax Agency/Sistema de Administración Tributaria, SAT), while from the demand side persons (individual taxpayers), firms, business and companies end users of the software application for eInvoice emission, as well as end user customers who receive the document as an official evidence of a purchase transaction and the accountants responsible of the tax' register and mandatory reports. Supporting the operations are the authorized folio control agencies, e-Invoice application suppliers, designated certifiers, and a number of training services providers and small consultants acting as intermediate receptors of the electronic documents.

Operational Context. With a long preparation history, from its legal acceptance in May 2000 [30], and the inclusion in the Fiscal Code in January 2004 [31], a technical standard (Official Norm-NOM 151) issue, the register and diffusion of the electronic signature certificate at country level since 2005, the systems application setting, the web system operation, to the general certification process and operational scheme development. This complex and long process, in which many players were involved, resulted in a technology and procedural platform - operated partially since middle last decade by major companies [32], mandatory from 2011 for firms with more than 4.0 MMP - will enter into operation in January $1^{\text {st }}, 2014$ for the country's active taxpayers (conformed by 39 million 478 thousand active tax payers. [33], in the range of more than 250,000 MXP annual income meaning a non official estimation of number adopters increase of one more million to be added to the 802,662 tax payers issuing e-Invoices in April 2013 [34].

\subsection{Research Approach}

Among the referred technology receivers population is an important group of firms in different stages of technology and information readiness [35,36], operating in the small retail business in models such as Pop \& Mom Stores and commerce of the kind distributed along the country territory $(1,740,522$ retail business, from which 908,161 are Pop \& Mom Stores [37]. For this importance research attention is attracted to this segment in Mexico adding the criteria of exploration in a region different from the country's Capital City or highly industrialized or commercial areas of the country. The selected region has registered a number of 42,345 economic units in the retail segment-from which 14,032 are small retail stores from the Pop \& Mom type-providing employment to 129,274 persons (SIEM/Mexican Enterprises Information System 2010).

Using a mixed research approach, the study was structured in two stages, being the first of qualitative nature in which materials collected from the technology source (SAT webpage) as well as from the technology usersto-be through semi structured interviews to identify their knowledge and awareness regarding e-Invoice legal platform, the electronic document components as well as about the technical infrastructure required for the use, the players involved and available to support the operation of the compulsory procedure on the web. In this stage, to learn about the technology characteristics that could influence the diffusion process, a wide array of software solutions suppliers for the internal firm operation were analyzed, deriving from this analysis the operational requirements from the users' perspective.

Supported by qualitative analysis results, the second stage of the research project consisted in a quantitative study performed with data collected from a convenience sample comprised by 137 small retail active business operating in the selected region of the country, that $a c$ cepted to provide direct data through a 5 set of items questionnaire oriented to identify their technology readiness in terms of technology infrastructure and skills to operate under the electronic invoice legal procedure, as well as their perceived barriers for the diffusion. Due to prevailing contextual factors such as security issues and lack of tradition to collaborate in research activities, the firms were reluctant to provide information of any kind, being visited almost 500 stores in three cities of the region, finally was possible to collect 137 complete questionnaires, which covers Factor Analysis criteria of the sample size $[38,39]$. Using Likert Scale, the first set of items of the questionnaire focused on the adopter perceptions regarding advantages or perceived usefulness of the technology and risks associated to the e-Invoice use, while the second set of items targets the external influ- 
ences for the use. In this instrument a third set of items focus on the technology readiness in terms of object transfer (e-invoice components) knowledge, the awareness of the e-Invoice application, technology infrastructure availability, and the existing competences required to operate it. Each set of items was grouped in new, generalized meaningful dimensions using Factor Analysis technique [38,39]. The principal components method was used for factor extraction while to identify the factor solution number criteria recommended by the literature were used: scree-plot graphic, eigen-values associated to each factor and variance percentage explained by the number of factors solution. This paper presents the results of the quantitative analysis.

\section{Findings}

\subsection{Object Transfer (e-Invoice) Knowledge}

As suggested by Spinardi [23], effective Technology Transfer requires careful handling of the tacit knowledge of its developers, task assumed in this research by the technology source represented by the Government Agency (SAT) and by the software suppliers. The end users group reveals a wide range of persons and firms involved with the document processing for different purposes, being then an adopting firm and an end user as mentioned by Leonard-Barton [27]. Transfer process takes place between the Tax Agency and the adopter firms while diffusion takes place among end users. In this context, Tax Agency transfer actions are mainly oriented to provide free information and technical assistance on line regarding the operational requirements and the web based process (www.sat.gob.mx) to be followed for the transactions. Supporting the transfer process, a brief media campaign about the e-Invoice compulsory introduction for the tax payers was promoted in the last two months of 2010. Further information from the source was founded for 2013 [40,41]. The general information provided in 2010 from the technology source to the adopters is summarized in a 10 points guideline used as key input to identify user's knowledge about the general e-Invoice process.

1) Look for general information for e-Invoice use at SAT web page.

2) Verify that the firm has accountancy registers in electronic applications.

3) Assess current accountancy registers application.

4) Identify if an "addenda" is required.

5) Identify if complementary nodes from the SAT are required.

6) Acquire an e-Invoice software solution certified by the SAT.

7) Obtain from the SAT an electronic signature cer- tificate.

8) Validate the software solution operation in internal systems.

9) Test software solution operation with e-Invoice receptor clients.

10) Provide training to the Software application users.

Regarding the certification and folios issue, a payment must be done by the tax payer in the same way that a printed paper invoice must be paid $(100$ folios $=$ approximately $\$ 80$ USD per year) therefore is perceived as expensive. On the skills arena, Software solution suppliers' main marketing feature is to provide training for the direct user, being clearly a technology transfer by sale in which the buyer pays the price for the full rights to use the technology solution and for the training required to operate it, a popular tool for training is a free demo on the supplier's webpage. The effectiveness of the transfer actions regarding information is explored by means of the knowledge of guidelines items analysis, considering it as the first stage required by the adopter to take an innovation decision.

From the information variable set (Table 1), a three Factor solution in regard of technology knowledge resulted from the Factor Analysis after the Varimax rota-

Table 1. Knowledge resulting from the information actions. Factor analysis results.

\begin{tabular}{|c|c|c|c|c|}
\hline Variable & Factor1 & Factor2 & Factor3 & Communality \\
\hline \multicolumn{5}{|c|}{1.1 e-Invoice components } \\
\hline & 0.809 & 0.235 & 0.380 & 0.853 \\
\hline \multicolumn{5}{|c|}{$1.2 \mathrm{e}$-Invoice issue process } \\
\hline & 0.702 & 0.091 & 0.260 & 0.569 \\
\hline \multicolumn{5}{|c|}{ 1.3 Electronic Signature Certificate } \\
\hline & 0.800 & 0.457 & 0.281 & 0.927 \\
\hline \multicolumn{5}{|c|}{ 1.4 Certification process } \\
\hline & 0.745 & -0.091 & 0.116 & 0.576 \\
\hline \multicolumn{5}{|c|}{ 1.5 Software application suppliers } \\
\hline & 0.900 & -0.268 & 0.003 & 0.881 \\
\hline \multicolumn{5}{|c|}{ 1.6 Addenda content and structure } \\
\hline & 0.691 & -0.689 & 0.135 & 0.969 \\
\hline \multicolumn{5}{|c|}{1.7 Folio acquisition process } \\
\hline & 0.537 & -0.018 & -0.557 & 0.599 \\
\hline \multicolumn{5}{|c|}{ 1.8 Internet Access } \\
\hline & 0.699 & 0.180 & -0.548 & 0.821 \\
\hline \multicolumn{5}{|c|}{ 1.9 Computer availability } \\
\hline & 0.714 & 0.153 & -0.402 & 0.695 \\
\hline \multicolumn{5}{|c|}{ 1.10 Skilled personnel for e-Invoice issue } \\
\hline & 0.748 & 0.067 & -0.327 & 0.671 \\
\hline \multicolumn{5}{|c|}{ 1.11 Electronic Accountancy System } \\
\hline & 0.800 & 0.457 & 0.281 & 0.927 \\
\hline \multicolumn{5}{|c|}{ 1.12 Operation test with business partners } \\
\hline \multicolumn{5}{|l|}{ Variance } \\
\hline \multirow{2}{*}{$\%$ Var } & 6.5904 & 1.5703 & 1.2988 & 9.4595 \\
\hline & 0.549 & 0.131 & 0.108 & 0.788 \\
\hline
\end{tabular}


tion. The first factor structure reveals that participant firms have knowledge of the software application suppliers (0.900 highest load), the e-Invoice components or data to be included (0.0809), the need of an electronic signature certificate $(0.800)$ and of the availability of an electronic accountancy system (0.800). As other variables such as computer and skilled personnel resulted highly loaded the first factor was termed Infrastructure Knowledge. In contrast, results of the second factor show little knowledge of the addenda component and of the suggested operational test with the firm's business partners, therefore the second factor receive the name of Issues Ignored. The third factor shows lack of knowledge about the folio acquisition process and the wide band internet access, being termed as Incomplete Knowledge.

Results from Table 1 suggest that firms are partially informed about the requirements for the e-Invoice adoption as determine by the steps of the process guideline. To operate the e-invoice process, knowledge about technology infrastructure should be completed with the folio numbering and the authentication procedure, while the operations requires to be tested with the main business partners systems due to the two way nature of the invoice. Incomplete information challenges the diffusion process, if the firm considers that buying the software application and obtaining the electronic signature certificate is the unique requisite to run the e-invoice operations. These lead to consider that the innovation itself is perceived as complex and difficult to operate, providing a reason to create a barrier for adoption.

\subsection{Perceived Technology Usefulness}

Focused on the adopter perceptions regarding advantages or perceived usefulness of the technology is a second set of results. Addressed in the form of ease-of-use and usefulness of technology [42], an attitude is defined as "a psychological tendency that is expressed by evaluating a particular entity with some degree of favor or disfavor" [43]. Davis [42], pioneered advances in Theory of Reasoned Action [44], by postulating that Perceived Usefulness (PU) and Perceived Ease of Use (PEU) are key determinants that inevitably lead to the actual Usage (U) of a particular technology or system, defining Perceived Usefulness as the extent to which a person believes that using a particular system or technology will enhance his or her job performance, while Perceived Ease of Use is defined as the extent to which a person believes that using the particular system or technology will be free of effort. PEU is usually related to the intrinsic characteristics of IT (ease of use and ease of learning the technology), while PU relates to extrinsic factors like efficiency and effectiveness. Perceived Usefulness is a key driver of behavioral intention to utilize a specific technology.
Results in Table 2 present a satisfactory two factor solution for the e-Invoice perceived usefulness, being factor one is structured by three items related to operational efficiencies and one item related to competitiveness. In the first group of items the perceived benefits derived from the accountancy operations register $(0.948)$ belongs to internal procedures while alignment to electronic payments (0.828) and order management support (0.785) are transactional operations in nature. Dominant items structure reveals that e-Invoice usefulness is perceived to gain internal efficiencies and to improve transactions with business partners, mainly in the invoice-payment cycle which is a key issue for the firms' working capital management. In factor 2 the dominant item is the negative perception of the use of the innovation to support new customer integration $(-0.992)$, followed by the $(-0.659)$ negative usefulness perception to provide accuracy for inventory control, suggesting lack of knowledge or information regarding the addenda role in the electronic document. Results reveal that the adopters are not fully aware of the benefits of the innovation being this a possible reason of indifference for the implementation.

\subsection{Readiness}

From the process view, Technology Transfer relies on organizational and individuals capabilities as key success issues, decisions about technology use and implementation require the adopter readiness in two arenas: technology infrastructure (tangible resources) and developed skills to operate such infrastructure (intangible resources). This view also involves the dissemination of know-how and technical information, as well as further adoption by

Table 2. Technology usefulness perception. operational advantages from e-invoice use.

\begin{tabular}{|c|c|c|c|}
\hline Variable & Factor 1 & Factor 2 & Communality \\
\hline \multicolumn{4}{|c|}{ 2.1 Order Management Support } \\
\hline & 0.785 & -0.331 & 0.725 \\
\hline \multicolumn{4}{|c|}{ 2.2 Provides Accuracy for Inventory Control } \\
\hline & 0.429 & -0.659 & 0.619 \\
\hline \multicolumn{4}{|c|}{ 2.3 Helps new clients integration } \\
\hline & 0.043 & -0.992 & 0.985 \\
\hline \multicolumn{4}{|c|}{ 2.4 Improves customer support and service } \\
\hline & 0.715 & 0.017 & 0.511 \\
\hline \multicolumn{4}{|c|}{ 2.5 Aligned to electronic payment process } \\
\hline & 0.828 & -0.258 & 0.752 \\
\hline \multicolumn{4}{|c|}{ 2.6 Benefits register in accountancy operations } \\
\hline & 0.948 & -0.267 & 0.971 \\
\hline \multicolumn{4}{|l|}{ Variance } \\
\hline & 2.8971 & 1.6660 & 4.5631 \\
\hline \multicolumn{4}{|l|}{$\%$ Var } \\
\hline & 0.483 & 0.278 & 0.761 \\
\hline
\end{tabular}


users as stated by Tassey [26].

Results in Table 3 reveal that firms have high level of perceived readiness in both technology infrastructure availability (0.754) and staff skills to operate it $(0.816)$, willing to be trained to operate the e-Invoice software application (0.760), a solid change culture and even a business plan to face investments needed. Such a declared fertile context is surprising in the micro and small retail business format of the country of the analysis, and calls to deep into the analysis in order to identify non declared barriers for diffusion, mainly under the light of results about technology based business practices in retail industry firms [36] and in technology infrastructure research performed in this segment of firms along the Mexican-American border [45].

As the user has training needs to respond to the adopter decisions, external influences for the diffusion are explored in four variables related to the interaction between suppliers and customers in a Supply Chain Management context (Table 4), where the technology diffusion driver is the dominant business partner $(0.857)$ and without the e-Invoice competitive position could be lost $(-736)$. In retail industry Technology dissemination is made mainly by dominant business partners such as large store chains who look for supplier development or by Multinational suppliers who are challenged by scattered clients' distribution. Such a context seems to be consistent with Leonard-Barton [26] point that usually the end user of the innovation is not the decision maker person, therefore the end user is not subject to the different stages of an innovation decision making process.

Table 3. Technology readiness. technology infrastructure.

\begin{tabular}{|c|c|c|c|}
\hline Variable & Factor 1 & Factor 2 & Communality \\
\hline \multicolumn{4}{|c|}{$\begin{array}{l}\text { 3.1 Staff has developed skills and competences to use computers anc } \\
\text { internet }\end{array}$} \\
\hline & 0.754 & 0.200 & 0.609 \\
\hline \multicolumn{4}{|c|}{ 3.2 Training for the e-Invoice use is a firm priority } \\
\hline & 0.760 & 0.483 & 0.812 \\
\hline \multicolumn{4}{|c|}{$\begin{array}{l}\text { 3.3 Organizational culture has the flexibility required to get adapted for } \\
\text { e-Invoice use }\end{array}$} \\
\hline & 0.829 & 0.280 & 0.766 \\
\hline \multicolumn{4}{|c|}{ 3.4 The firm promotes e-Invoice use among suppliers and customers } \\
\hline & 0.205 & 0.317 & 0.143 \\
\hline \multicolumn{4}{|c|}{ 3.5 The firm is confident in the staff skills for e-Invoice use } \\
\hline & 0.816 & 0.294 & 0.752 \\
\hline \multicolumn{4}{|c|}{ 3.6 Technology investment is sufficient to start e-Invoice use } \\
\hline & 0.176 & 0.984 & 1.000 \\
\hline \multicolumn{4}{|c|}{$\begin{array}{l}3.7 \text { The firm has developed a business plan for Technology investmen } \\
\text { required to operate e-Invoice }\end{array}$} \\
\hline & 0.347 & 0.700 & 0.611 \\
\hline \multicolumn{4}{|l|}{ Variance } \\
\hline & 2.6945 & 1.9983 & 4.6928 \\
\hline \multicolumn{4}{|l|}{$\%$ Var } \\
\hline & 0.385 & 0.285 & 0.670 \\
\hline
\end{tabular}

Table 4. Diffusion drivers. e-Invoice Use within retail industry.

\begin{tabular}{|c|c|c|c|}
\hline Variable & Factor 1 & Factor 2 & Communality \\
\hline \multicolumn{4}{|c|}{$\begin{array}{l}\text { 4.1 Rules for e-Invoice process are defined by the firm's main business } \\
\text { partners }\end{array}$} \\
\hline & 0.666 & -0.558 & 0.755 \\
\hline \multicolumn{4}{|c|}{$\begin{array}{l}\text { 4.2 Decisions regarding e-Invoice software application and technology } \\
\text { infrastructure are made by the firm's main business partners }\end{array}$} \\
\hline & 0.857 & -0.414 & 0.906 \\
\hline \multicolumn{4}{|c|}{ 4.3 In retail industry e-Invoicing is a major business practice } \\
\hline & 0.447 & -0.637 & 0.606 \\
\hline \multicolumn{4}{|c|}{ 4.4 Without e-Invoice use the firm loses its competitive position } \\
\hline & 0.352 & -0.736 & 0.665 \\
\hline \multicolumn{4}{|l|}{ Variance } \\
\hline & 1.5015 & 1.4303 & 2.9318 \\
\hline \multicolumn{4}{|l|}{$\%$ Var } \\
\hline & 0.375 & 0.358 & 0.733 \\
\hline
\end{tabular}

\subsection{Perceived Barriers and Advantages}

To analyze the diffusion of the e-Invoice five sources of impediments were considered and explored by means of a set of five variables: 1) barriers related to the usefulness of technology [42], measured by the perceptions regarding the impact in the efficiency of the business cycle; 2) barriers from the operational costs view, measure by the perception of cost reduction for integration with business partners such as in supply chain management practices; 3 ) perceived absence of benefits, also in the technology usefulness field; 4) barriers related to technology return on investment risk; and 5) barriers perceived about the security of the transactions, measured by the preference for the traditional paper invoice. When positive, the selected set of variables turns into a perceived advantage.

A dual environment is identified from the results of Table 5. Factor 1 structure is dominated by the positive perceptions regarding advantages in cost reduction (0.815) and the high ROI risk, which is explained by the nonalways-known cost of each invoice issue process. Factor 2 reveals a perceived security risk that could be interpreted either by the resistance to change or by the need to have physical control on the transaction document. In short, for this group of firms the electronic process is not sufficient to meet security risks being a major concern that their investment could fail if the right technology decisions are not taken or due to the non-profit nature of the technology to be implemented to run the invoicing process.

\section{Conclusions}

Results of this research are consistent with LeonardBarton's [11] statement that the implementation characteristics of the technology — such as the one described 
Table 5. Perceived barriers and advantages.

\begin{tabular}{cccc}
\hline Variable & Factor 1 & Factor 2 & Factor3 \\
\hline 5.1 e-Invoice use leads to operational Efficiency of the business cycle \\
0.470 & 0.327 & 0.328
\end{tabular}

5.2 Operational costs are reduced by the use of e-Invoice for business practices integration

$$
0.815 \quad 0.217 \quad 0.712
$$

5.3 There is no evidence of benefits obtained due to the use of e-Invoice

$$
0.698 \quad 0.463 \quad 0.702
$$

5.4 Technology investment for E-Invoice operation has high ROI risk

$$
\begin{array}{lll}
0.734 & 0.119 & 0.553
\end{array}
$$

5.5 e-Invoice has higher risks than traditional paper document

$$
\begin{array}{lll}
0.216 & 0.951 & 0.951
\end{array}
$$

Variance

1.9585

1.2862

3.2448

$\%$ Var

0.392

0.257

0.649

here-can impact the adoption and diffusion. This complexity provides one reason to explain why the adoption of advanced integration technologies that enable firms to execute their business transactions electronically is still relatively low, especially among SMEs and in developing countries, such as recent research findings reports [46, 47]. This also seems to be true in the context of the obtained results due to the number of adopters in relation of the size of the tax payer population. For such a number of firms targeted for a country level technology transfer, results suggest that the technology readiness analysis seems to be a useful tool to gain deep understanding of the context of application ([24].

A relevant conclusion emerges from firm's declaration regarding technology readiness far to be considered as an adoption barrier, contrasted con the declared practice of produce paper documents by printing the electronic invoice message to "keep a hard copy" reflecting a technology culture under construction far related to the business culture characteristics of profit orientation and efficiency search as means for profit creation [48].

The analysis leads to conclude that technology readiness for the small business segment is not completed, as identified by partial levels of information regarding certificate and folios payment, insufficient information about standardized software, different criteria for addenda structure, training under software applications suppliers hands, complex ease of use of the technology and a strong traditional culture with little understanding of the nonprofit nature of the technology investments. These are some of the challenges to overcome in the technology transfer arena, while the perceived advantages related to operational cost reduction and efficiency are strong reasons to be used as key reasons to reach the technology diffusion goals.

While the resolution of these issues is in progress, the effort continues and more firms are added to the change. So far, Technology Culture is extended through the incorporation to e-Invoice use into operations of other type of business firms such as gas stations, large supermarket chains, few mini supermarket stores, government agencies and even laundry business, following a diffusion strategy "by imitation". For those taxpayers in the range of 250,000 MXP annual income that still have printed invoice vouchers, ready or not the use of e-Invoice could not be postponed further than the beginning of year 2014 . From the research study can be drawn several lessons regarding the imposing of a substantial burden on would be technology adopters as mentioned by Fichman [10], and about the importance of stimulate awareness among the new population of users, coordinated actions among transfer players and the need to develop a safety net in terms of assistance. In such technology transfer context, wide array of business opportunities rise for business consultants and training firms.

\section{REFERENCES}

[1] X. Y. Yu, "International Economic Law," University Press, Nanjing, 1990.

[2] P. G. Abbott, "Technology Transfer in the Construction Industry Infrastructure and Industrial Development," Special Report No. 223, The Economist Intelligence Unit, The Economist Publications Ltd., London, 1985.

[3] J. D. Roessner, "Technology Transfer," In: C. Hill, Ed., Science and Technology Policy in the US. A Time of Change, Longman, London, 2000.

[4] L. M. Zhao and A. Reisman, "Toward Meta Research on technology-Transfer," IEEE Transactions on Engineering Management, Vol. 39, No. 1, 1992, pp. 13-21.

[5] B. Bozeman, "Technology Transfer and Public Policy: A Review of Research and Theory," Research Policy, Vol. 29, No. 4-5, 2000, pp. 677-625.

[6] W. Souder, "Managing New Products Innovations," D. C. Heath Canada, Limited, Ma. Lexington, 1987.

[7] A. Rubenstein, "Managing Technology in a Decentralized Firm," Wiley, New York, 1989.

[8] E. Rogers, "Diffusion of Innovations," 5th Edition, Free Press, New York, 2003, p. 12.

[9] D. Leonard-Barton and E. Rogers, "Horizontal Diffusion: An Alternative Paradigm to the Classical Diffusion Model," Working Paper No. 1284-81, Alfred P. Sloan School of Management, Massachusetts Institute of Technology, Cambridge, 1981.

http://opensource.mit.edu/papers/1569088836.pdf

[10] R. Fichman, "Information Technology Diffusion: A Review of Empirical Research," Proceedings ICIS'92. Proceedings of the 13th International Conference on Information Systems, University of Minessota, Mineapolis, 
1992, pp. 195-206.

[11] D. Leonard-Barton and I. Deschamps, "Managerial Influencies in the Implementation of New Technology," Management Science, Vol. 34, No. 10, 1988, pp. 12521265.

[12] G. C. Moore and I. Benbasat, "Development of an Instrument to Measure the Perceptions of Adopting an Information Technology Innovation," Information Systems Research, Vol. 2, No. 3, 1991, pp. 192-222. http://dx.doi.org/10.1287/isre.2.3.192

[13] E. Roberts and L. Frohman, "Strategies for Improving Research Utilization," Technology Review, Vol. 80, No. 5. 1978, pp. 32-39.

[14] E. Roberts, "What We Have Learned: Managing Innovation and Invention," Research-Technology Management, Vol. 50, No. 1, 1988, pp. 11-19.

[15] G. Gaynor, "Innovation by Design," American Management Association, New York, 2002, p. 84.

[16] D. Leonard-Barton, "The Intra-Organizational Environment: Point-to-Point vs. Diffusion," In: F. Williams and D. Gibson, Eds., Technology Transfer, A Communication Perspective, SAGE Publications, Thousand Oaks, 1990, pp. 43-62.

[17] L. Smits, J. Leyten and P. den Hertog, "Technology Assessment and Technology Policy in Europe: New Concepts, New goals, New Infrastructure," Policy Science, Vol. 28, No. 3, 1995, pp. 271-299.

[18] P. K. De, "Gap between Strategy and Management of Technology: A Review of Indian Scenario," In: Hosni and Kalil, Eds., Management of Technology. Internet Economy: Opportunities and Challenges for Developed and Developing Regions of the World, Elsevier, Ltd., Amsterdam, 2004.

[19] L.-H. Richard, "From Technology Transfer to Knowledge Transfer. A Study of International Joint Venture Projects in China," Proceedings of the 12th International Conference on Technology Management, (IAMOT), Nancy, 1315 May 2003, pp. 1-16. www.iamot.org/paperarchive/li-hua.pdf

[20] E. Autio and T. Laamanen, "Measurement and Evaluation of Technology Transfer: Review of Technology Transfer Mechanisms and Indicators," International Journal of Technology Management, Vol. 10, No. 7-8, 1995, pp. 643-664.

[21] A. Thomas, "Acquisition and Licensing of Intellectual Property," Managerial Law, Vol. 40 No. 6, 1998, pp. 515.

[22] R. Megantz, “Technology Management: Developing and Implementing Effective Licensing Programs," John Wiley \& Sons Inc., New York, 2002.

[23] G. Spinardi, "Defense Technology Enterprises," Science and Public Policy, Vol. 19, No. 4, 1992, pp. 198-206.

[24] J. Mollas-Gallart and T. Sinclair, "From Technology Generation to Technology Transfer: The Concept and Reality of the 'Dual-Use technology Centers'," Economic and Social Research Council, International Conference on Technology Policy and Innovation, Lisbon, 3-5 August
1998, pp. 1-10.

[25] P. Shapira and S. Rosenfeld, "An Overview of Technology Diffusion Policies and Programs to Enhance the Technological Absorptive Capabilities of Small and Medium Enterprises," Organization for Economic Cooperation Development (OECD), Directorate of Science, Technology and Industry, Paris, 1996. www.gatech.edu/mod

[26] G. Tassey, "Technology Infrastructure and Competitive Position,” Kluwer Academic Publishers, Norwell, 1992. http://dx.doi.org/10.1007/978-1-4615-3608-6

[27] D. Leonard-Barton, "Applying Innovations Diffusion Theory to the Management of Change," Working Paper No. 1295-82, Alfred P. Sloan School of Management. Massachusetts Institute of Technology, Cambridge, 1982. http://dspace.mit.edu/bitstream/handle/1721.1/46833/appl yinginnovati00leon.pdf? sequence $=1$

[28] H. Ergas, "Does Technology Policy Matter?" In: B. Guile and H. Brooks, Eds., Technology and Global Industry: Companies and Nations in the World Economy, National Academy Press, Washington DC, 1987, pp. 191-280.

[29] D. Sahal, "The Form of Technology," In: D. Sahal, Ed., The Transfer and Utilization of Technical Knowledge, Lexington Publishing, Lexington, 1982, pp. 125-139.

[30] Federation Official Bulletin January 5th 2004. Mexican Government, Mexico. DOF. Diario Oficial de la $\mathrm{Fe}$ deración del 5 de Enero del 2004.

[31] Federation Official Bulletin May 30th, 2000, Mexican Government, Mexico. DOF. Diario Oficial de la Federación del 30 de Mayo del 2000.

[32] V. E. Erosa and P. Arroyo, "Characteristics of Firms Interested in e-Invoice Adoption, in Change Commitment," Mexican Association for Electronic Commerce, Mexico, 2003, pp. 269-291. (Caracteristicas de las empresas que tienen interés en incorporarse a la Factura Electronica. In El Compromiso con el Cambio: Identificando Oportunidades de Negocios en la Cadena de Valor. AMECE. Asociacion Mexicana de Estandares para el Comercio Electronico. Direccion de Investigacion y Desarrollo. México, Mayo 2003.)

[33] Tax Management System, "Tax Management Report," 2013. Mexico, 2013, pp. 4. SAT. Sistema de Administracion Tributaria. Informe Tributario y de Gestion. 2 Trimestre 2013. Secretaria de Hacienda y Credito Publico. Sistema de Administracion Tributaria. 2013.

http://www.sat.gob.mx/sitio_internet/informe_tributario/i nforme2013t2/tributario.pdf

$\mathrm{ftp}: / / \mathrm{ftp} 2$.sat.gob.mx/asistencia_servicio_ftp/publicacione s/boletines/com2012_121.pdf

[34] L. F. S. Velazco, "E-Invoice Statistics in April 30, 2013," Estadisticas de la Factura Electronica. Suplementos Corporativos, S. A. de C. V. Suplemento Factura Electronica, 2013.

http://www.suplementofacturacionelectronica.com/2013/0 6/estadisticas-al-30-de-abril-de-2013/

[35] V. E. Erosa and P. Arroyo, "Readiness Analysis for Data Base Synchronization between Clients and Suppliers," Informatics Policy Bulletin/ Boletín de Politica Infor- 
matica. INEGI. Mexico, 2003. Año XXVI. Numero 1, pp. 31-5.

http://www.inegi.org.mx/inegi/contenidos/espanol/prensa/ contenidos/Articulos/tecnologia/capacidademp.pdf

[36] V. E. Erosa. "Technology Gap among Suppliers and Pop \& Mom Stores as a Key Distribution Cost Issue," Management of Engineering and Technology, 2008. Proceedings PICMET 2008. Portland International Conference on Management of Engineering and Technology 2008, Capetown, 27-31 July 2008, pp. 2623-2630.

[37] National Institute of Statistics, Geography and Informatics, "Statistics Yearbook of the United Mexican States," Mexico 2013, pp. 470, Table 16.1. INEGI. 2013. Anuario Estadistico de los Estados Unidos Mexicanos, 2012-2013. 470. Cuadro 16.1.

[38] J. Stevens, "Applied Multivariate Statistics for the Social Sciences," Lawrence Erlbaum Associates, Hissdale, 1986.

[39] J. Hair, W. Black, B. Babin, R. Anderson and R. Tatham, "Multivariate Data Analysis," 6th Edition, MacMillan Publishing Company, New York, 2006.

[40] Tax Management System, Mexico, "Information about e-Invoice (2013)," Secretaria de Hacienda y Credito Publico. SAT. Sistema de Administracion Tributaria Informacion sobre Factura Electronica (2013). 2013. $\mathrm{ftp} / / / \mathrm{ftp} 2$.sat.gob.mx/asistencia_servicio_ftp/publicacione s/cfd/PyRFactElect.pdf

[41] Tax Management System, Mexico, "Assistance about eInvoice (2013)," Secretaria de Hacienda y Credito Publico. SAT. Sistema de Administracion Tributaria Asistencia sobre Factura Electronica (2013). 2013. http://www.sat.gob.mx/sitio internet/asistencia contribuy ente/principiantes/comprobantes_fiscales/66_19339.html

[42] F. D. Davis, "Perceived Usefulness, Perceived Ease of Use, and User Acceptance of Information Technology", MIS Quarterly, Vol. 13, No. 3, 1989, pp. 319-339.

\section{http://dx.doi.org/10.2307/249008}

[43] A. Eagly and S. Chaiken, "The Psychology of Attitudes," Harcourt, Brace, Jovanovich, Fort Worth, 1993, p. 1.

[44] M. Fishbein and I. Ajzen, "Belief, Attitude, Intention and Behavior: An introduction to Theory and Research," Addison Wesley, Reading, 1975.

[45] V. E. Erosa, "Comparative Analysis of Technology Based Business Practices among Retail Industry Firms. A Binational Approach between Tamaulipas. Mexico and Texas USA," Mexico-United States Research Journal. CIMEXUS, Vol. V, No. 2 July-December, 2010, pp. 163-202. Analisis comparativo de las practicas de negocio basadas en tecnologia en empresas del Sector Comercio Minorista. Un enfoque binacional en la zona fronteriza TamaulipasTexas. CIMEXUS. Revista de Investigaciones MexicoEstados Unidos, 2010

[46] T. Janner, F. Lampathaki, V. Hoyer, S. Mouzakitis, Y. Charalabidis and C. Schroth, "A Core Component-Based Modelling Approach for Achieving e-Business Semantics Interoperability," Journal of Theoretical and Applied Electronic Commerce Research, Talca, 2008, Vol. 3, No. 3, 2008, pp. 1-16.

[47] R. Odigie and L. Hua, "Unlocking the Channel of Tacit Knowledge Transit: The Concept of Technology Transfer in Developing Countries," In: CAMOT 2008 International Conference Proceedings (Hendrix, Ed.) Technology Management and Innovation in China. Beijing, 2008. siif.croatia.com/hr/service/download/file/id/292

[48] V. E. Erosa, "Dealing with Cultural Issues in the Triple Helix Model Implementation: A Comparison among Government, University and Business Culture," Procedia-Social and Behavioral Sciences, Elsevier, Vol. 52, 2012, pp. 25-34. 